\title{
Study of the correlation between toxic, essential and macronutrients in the blood serum of stud horses
}

\author{
Valery Kalashnikov, Mikhail Atroshchenko*, Alina Sinyakina, Natalya Frolova, and Olga \\ Shirokova
}

All-Russian Research Institute for Horse Breeding, set. Divovo, Ryazan region, Rybnovsky district, 391105, Russia

\begin{abstract}
Studies were conducted to assess the elemental composition of the blood serum of 39 Arabian pure breed stud horses. The correlation between the content of toxic elements in the blood serum: aluminum ( $\mathrm{Al}$ ), arsenic $(\mathrm{As})$, cadmium $(\mathrm{Cd})$, lead $(\mathrm{Pb})$, tin $(\mathrm{Sn})$, mercury $(\mathrm{Hg})$, essential trace elements: cobalt $(\mathrm{Co})$, chromium $(\mathrm{Cr})$, copper $(\mathrm{Cu})$, iron $(\mathrm{Fe})$, iodine $(\mathrm{I})$, manganese $(\mathrm{Mn})$, selenium (Se), zinc $(\mathrm{Zn})$ and macronutrients: calcium $(\mathrm{Ca})$, potassium $(\mathrm{K})$, magnesium $(\mathrm{Mg})$, phosphorus $(\mathrm{P})$ was studied. A negative correlation was established between the content of mercury and iron in the blood serum of stud horses $(\mathrm{r}=-0.34 ; \mathrm{p}=0.04)$. A negative correlation was also found between the levels of cadmium and calcium in the blood serum $(r=-0.40 ; p=0.02)$. The establishment of these correlations suggests the presence of competitive relations between these elements in the body of horses. Positive correlations were established between the content of toxic elements in the blood serum: $\mathrm{Al} / \mathrm{As}(\mathrm{r}=0.38 ; \mathrm{p}=0.02)$, $\mathrm{Al} / \mathrm{Pb} \quad(\mathrm{r}=0.41 ; \mathrm{p}=0.009), \quad \mathrm{Al} / \mathrm{Sn} \quad(\mathrm{r}=0.56 ; \mathrm{p}=0.002), \quad \mathrm{As} / \mathrm{Sn} \quad(\mathrm{r}=0.46$; $\mathrm{p}=0.0003), \mathrm{Pb} / \mathrm{Sn}(\mathrm{r}=0.32 ; \mathrm{p}=0.05)$.
\end{abstract}

\section{Introduction}

In modern horse breeding, one of the main trends in the field of reproduction biology is the study of various exogenous and endogenous factors and their impact on reproductive health and the resistance of germ cells to cryopreservation [1], [2]. The state of the environment is important in the vital activity of the animal body. Environmental pollution by human industrial activity leads to a violation of the balance of mineral elements in water and soil, which contributes to the development of microelementosis [3], [4]. Micro- and macronutrients contribute to all the metabolic processes of the body: synthesis of proteins, fats, carbohydrates, maintaining osmotic pressure and acid-base balance. The animal body, which exceeds the normative values of the concentration of toxic elements, experiences irregularities in the work of various organs and systems [4]. Toxic elements compete with essential elements and can lead to their deficiency.

\footnotetext{
* Corresponding author: atromiks-77@mail.ru
} 
Elements having similar physical and chemical properties or size of atoms can actively interact or compete in the structures responsible for their absorption, transport or metabolism. There are such types of interaction between elements as synergism and antagonism [5]. Synergy causes an increase in the aftereffect of elements (for example, the sum of the concentrations of zinc and copper is 5 times more toxic than the excess of these elements separately) [5]. Ion antagonism is manifested as competition between different ions of the same valence, and between ions of different valence, it leads to inhibition of the intake of another element into the body, more often from another group [6]. Currently, one of the most relevant areas of scientific research is the study of the correlation between various elements in the human body and animals.

The purpose of the study is to study the effect of toxic elements on the content of essential elements and macronutrients in the blood serum of stud horses.

\section{Material and methods}

The research was carried out in JSC "Tersk Stud Horse Farm No. 169" (Stavropol Territory), in the cryobiology laboratory of the FSBSI "All-Russian Research Institute for Horse Breeding" (Ryazan region) and in the laboratory of the ANO "Center for Biotic Medicine"(city of Moscow) in 2018-2021. 39 purebred Arabian stud horses aged from 4 to 21 years (on average $11.2 \pm 0.8$ years) were used in the experiments.

Blood collection from each stud horse from the jugular vein was carried out once on an empty stomach before morning feeding during the breeding season (March-April). The blood samples were centrifuged at $1500 \mathrm{rpm}$ for 20 minutes and the serum was stored at -18 ${ }^{\circ} \mathrm{C}$ until the analysis was carried out.

The concentration of toxic elements in the blood serum: aluminum (Al), arsenic (As), cadmium $(\mathrm{Cd})$, lead $(\mathrm{Pb})$, tin $(\mathrm{Sn})$, mercury $(\mathrm{Hg})$, essential trace elements: cobalt $(\mathrm{Co})$, chromium $(\mathrm{Cr})$, copper $(\mathrm{Cu})$, iron $(\mathrm{Fe})$, iodine $(\mathrm{I})$, manganese $(\mathrm{Mn})$, selenium $(\mathrm{Se})$, zinc $(\mathrm{Zn})$ and macronutrients: calcium $(\mathrm{Ca})$, potassium $(\mathrm{K})$, magnesium $(\mathrm{Mg})$, phosphorus $(\mathrm{P})$ were determined by atomic emission and mass spectrometry in the testing laboratory of the ANO "Center for Biotic Medicine" (city of Moscow) using the Elan 9000 mass spectrometer ("Perkin Elmer", USA) and the Optima $2000 \mathrm{~V}$ atomic emission spectrometer ("Perkin Elmer", USA).

The statistical analysis was carried out using the programs Microsoft Excel 2016 and Statistica 13 ("Stat Soft Inc.", USA). The data were processed using generally accepted methods of variational statistics and expressed in the form of median (Me), quartiles [Q1/Q3] and minimum ( $\min )$ and maximum (max) values. Spearman nonparametric correlation analysis was used to identify the relation between the indicators. The differences were considered statistically significant at $\mathrm{p} \leq 0.05$.

\section{Results and discussion}

To study the correlation between the concentrations of toxic and essential trace elements, as well as macronutrients, the concentrations of these elements in the blood serum of stud horses were determined.

Table 1. The content of toxic and essential trace elements, and the concentration of macronutrients in the blood serum of stud horses, $\mathrm{mcg} / \mathrm{g},(\mathrm{n}=39)$.

\begin{tabular}{|c|c|c|c|}
\hline Indicator & Me [Q1/Q3] & $\min$ & $\max$ \\
\hline \multicolumn{4}{|c|}{ Toxic elements } \\
\hline $\mathrm{Al}$ & $0.0154[0.0136 / 0.0177]$ & 0.0124 & 0.0561 \\
\hline
\end{tabular}




\begin{tabular}{|c|c|c|c|}
\hline $\mathrm{As}$ & $0.0015[0.0014 / 0.0016]$ & 0.0012 & 0.0024 \\
\hline $\mathrm{Cd}$ & $0.0001[0.0000 / 0.0001]$ & 0.0000 & 0.0001 \\
\hline $\mathrm{Pb}$ & $0.0002[0.0002 / 0.0005]$ & 0.0001 & 0.0504 \\
\hline $\mathrm{Sn}$ & $0.0000[0.0000 / 0.0001]$ & 0.0000 & 0.0002 \\
\hline $\mathrm{Hg}$ & $0.0002[0.0002 / 0.0002]$ & 0.0002 & 0.0004 \\
\hline $\mathrm{Co}$ & $0.0009[0.0009 / 0.0011]$ & 0.0006 & 0.0018 \\
\hline $\mathrm{Cr}$ & $0.0003[0.0003 / 0.0009]$ & 0.0003 & 0.0114 \\
\hline $\mathrm{Cu}$ & $0.9250[0.8110 / 1.0200]$ & 0.6560 & 1.4600 \\
\hline $\mathrm{Fe}$ & $1.9500[1.7200 / 2.4600]$ & 1.3500 & 4.0900 \\
\hline $\mathrm{I}$ & $0.0118[0.0098 / 0.0152]$ & 0.0070 & 0.0186 \\
\hline $\mathrm{Mn}$ & $0.0008[0.0007 / 0.0011]$ & 0.0005 & 0.0632 \\
\hline $\mathrm{Se}$ & $0.1620[0.1520 / 0.1810]$ & 0.1240 & 0.2080 \\
\hline $\mathrm{Zn}$ & $0.7520[0.6930 / 0.7990]$ & 0.6050 & 0.9520 \\
\hline $\mathrm{Ca}$ & Macronutrients & 106.00 & 161.00 \\
\hline $\mathrm{K}$ & $144.00[137.00 / 151.00]$ & 89.19 & 187.00 \\
\hline $\mathrm{Mg}$ & $142.00[120.00 / 163.00]$ & 18.10 & 27.05 \\
\hline $\mathrm{P}$ & $21.93[20.42 / 22.77]$ & 78.32 & 131.00 \\
\hline
\end{tabular}

Among the toxic trace elements in the blood serum of stud horses, the aluminum content prevails, on average $0.0154[0.0136 / 0.0177] \mathrm{mcg} / \mathrm{g}$, iron predominates among essential trace elements, on average $1.95[1.72 / 2.46] \mathrm{mcg} / \mathrm{g}$, and calcium prevails among macronutrients, on average 144.00 [137.00/151.00] mcg/g (Table 1).

The correlation between the content of toxic and essential trace elements, as well as macronutrients in the blood serum of stud horses was established (Table 2). Positive correlations were noted between the toxic elements $\mathrm{Al} / \mathrm{As}(\mathrm{r}=0.38 ; \mathrm{p}=0.02), \mathrm{Al} / \mathrm{Pb}(\mathrm{r}=0.41$; $\mathrm{p}=0.009), \mathrm{Al} / \mathrm{Sn}(\mathrm{r}=0.56 ; \mathrm{p}=0.002), \mathrm{As} / \mathrm{Sn}(\mathrm{r}=0.46 ; \mathrm{p}=0.0003), \mathrm{Pb} / \mathrm{Sn}(\mathrm{r}=0.32 ; \mathrm{p}=0.05)$. The combined effect of toxic elements that mutually affect each other is due to the chemical interaction of compounds with each other, as a result of which the animal body is exposed to additional negative effects [5].

Table 2. Spearman rank correlation coefficient (Rs) and p-value of the studied elements in blood serum.

\begin{tabular}{|c|c|c|c|}
\hline Element & Element & Rs & $\mathrm{p}$ \\
\hline $\mathrm{Hg}$ & $\mathrm{Fe}$ & -0.34 & 0.04 \\
\hline $\mathrm{Cd}$ & $\mathrm{Ca}$ & -0.40 & 0.02 \\
\hline $\mathrm{Al}$ & $\mathrm{As}$ & 0.38 & 0.02 \\
\hline $\mathrm{Al}$ & $\mathrm{Pb}$ & 0.41 & 0.009 \\
\hline $\mathrm{Al}$ & $\mathrm{Sn}$ & 0.56 & 0.002 \\
\hline $\mathrm{As}$ & $\mathrm{Sn}$ & 0.46 & 0.0003 \\
\hline $\mathrm{Pb}$ & $\mathrm{Sn}$ & 0.32 & 0.05 \\
\hline
\end{tabular}

Statistical processing of the obtained results revealed a negative correlation between the mercury concentration and the iron content in the blood serum of stud horses $(\mathrm{r}=-0.34$; $\mathrm{p}=0.04$ ). More than $90 \%$ of mercury in the blood is associated with the hemoglobin of red blood cells [7], therefore, with an increase in the concentration of mercury in the blood, iron deficiency can be observed. Insufficient amount of iron in the body leads to iron deficiency anemia, immune disorders, prolonged hypoxia, reduced processes of leukocytopoiesis, atony of skeletal muscles and many other pathological processes [4]. 
There was also a negative correlation between the content of cadmium and calcium in the blood serum of stud horses $(\mathrm{r}=-0.40 ; \mathrm{p}=0.02)$. High concentrations of cadmium disrupt phosphorus-calcium metabolism, and also destroy the metabolism of trace elements: zinc, copper, iron, manganese, selenium [8]. The studies of Kumar S. and Sharma A. (2019) describe that cadmium affects both male and female reproduction, impairs the synthesis and regulation of hormones, as well as the frequency of pregnancy or its outcome, even at lower doses [9]. This fact is confirmed by the research of Telisman S. et al. (2000), who found that the cadmium content in the blood significantly correlates with a decrease in mobility and an increase in the number of abnormal forms of spermatozoids [10]. With an increase in the concentration of cadmium, the level of calcium decreases, which can lead to cramps in the muscles of the extremities, periodontal disease, osteoporosis, disruption of the gastrointestinal tract, a decrease in hemostasis [6].

According to the results of the conducted studies, it can be noted that in the body of stud horses there are competitive relations between the content of mercury and iron, as well as between cadmium and calcium in the blood serum. The established positive correlations between some toxic elements allow to assume that such a relationship can enhance the effect of the negative impact of these elements on the animal body. The results obtained allow to significantly expand knowledge in the field of assessing the elemental status of horses.

\section{Conclusions}

Our studies allowed to determine the effect of the concentration of toxic elements on the content of essential trace elements and macronutrients in the blood serum of stud horses. The negative correlation was established between the mercury concentration and the iron content in the blood serum of stud horses $(r=-0.34 ; p=0.04)$. There was also a negative correlation between the content of cadmium and calcium in the blood serum of stud horses $(\mathrm{r}=-0.40 ; \mathrm{p}=0.02)$. The establishment of these correlations suggests the presence of competitive relations between these elements in the body of horses. There were also positive correlations between the content of toxic elements in the blood serum of stud horses: $\mathrm{Al} / \mathrm{As}(\mathrm{r}=0.38 ; \mathrm{p}=0.02), \mathrm{Al} / \mathrm{Pb}(\mathrm{r}=0.41 ; \mathrm{p}=0.009), \mathrm{Al} / \mathrm{Sn}(\mathrm{r}=0.56 ; \mathrm{p}=0.002), \mathrm{As} / \mathrm{Sn}$ $(\mathrm{r}=0.46 ; \mathrm{p}=0.0003), \mathrm{Pb} / \mathrm{Sn}(\mathrm{r}=0.32 ; \mathrm{p}=0.05)$.

\section{Acknowledgements}

The research was carried out with the support of the Russian Science Foundation (project No. 17-16-01109P), using the equipment of the Research Equipment Sharing Center "Collection of Genetic Resources" of the FSBSI "All-Russian Research Institute for Horse Breeding".

\section{References}

1. M.M. Atroshchenko, E.E. Bragina, A.M. Zaitsev, V.V. Kalashnikov, V.A. Naumenkova, A.M. Kudlaeva, E.V. Nikitkina, Nature Conservation Research 4(2), 7882 (2019) doi: 10.24189/ncr.2019.024

2. M.M. Atroshchenko, A.M. Kudlaeva, M.A. Fomina, V.V. Kalashnikov, A.M. Zaitcev, O.V. Denisova, D.G. Navasardyants, O.S. Belonovskaya, A.A. Pasko, IOP Conf. Series: Earth and Environmental Science 341, 012162 (2019) doi: 10.1088/1755$1315 / 341 / 1 / 012162$ 
3. V.A. Bagirov, V.V. Kalaschnikov, A.M. Zaitsev, M.M. Atroshchenko, S.A. Miroshnikov, O.A. Zavialov, A.N. Frolov, Sel'skokhozyaistvennaya biologiya 52(6), 1184-1193 (2017) doi: 10.15389/agrobiology.2017.6.1184eng

4. A.P. Avtsyn, A.A. Zhavoronkov, M.A. Rish, Human microelementoses, 496 (M.: Medicine, 1991)

5. A.Yu. Tarasov, S.B. Belogorov, D.V. Marchenko, Fundamentals of toxicology, 57 (Irkutsk: IGMU, 2015).

6. I. Loginova, Complex relationships between elements: antagonism and synergism, 37 (K.: Infoindustria, 2015)

7. L.E. Shitova, S.A. Bekeeva, Bulletin of KazNMU 1, 370-375 (2017)

8. S.V. Buryakov, E.V. Malysheva, A.V. Gulin, Vestnik TSU 18(4), 1317-1319 (2013)

9. S. Kumar, A. Sharma, Reviews on Environmental Health 34(4), 327-338 (2019) doi: 10.1515/reveh-2019-0016

10. S. Telisman, P. Cvitkovic, J. Jurasovic, A. Pizent, M. Gavella, B. Rocić, Environ Health Perspect 108(1), 45-53 (2000) doi: 10.2307/3454294 